\title{
Hidden in plain sight, Chaetopterus dewysee sp. nov. (Chaetopteridae, Annelida) - A new species from Southern California
}

\author{
Ekin TILIC ${ }^{1, *} \&$ Greg W. ROUSE ${ }^{2, *}$ \\ ${ }^{1,2}$ Scripps Institution of Oceanography, 9500 Gilman Drive, La Jolla, California 92093-0202, USA. \\ ${ }^{1}$ Institute of Evolutionary Biology and Animal Ecology, Rheinische Friedrich Wilhelms Universität \\ Bonn, An der Immenburg 1, 53121 Bonn, Germany. \\ *Corresponding authors: etilic@evolution.uni-bonn.de; grouse@ucsd.edu \\ ${ }^{1}$ urn:1sid:zoobank.org:author:89205DA4-C863-49CA-9C9B-4EFCF53B43B5 \\ ${ }^{2}$ urn:1sid:zoobank.org:author:F4AAFAE4-85D9-44CA-8290-E0FC614E1983
}

\begin{abstract}
We describe a long-unnamed Chaetopterus Cuvier, 1830 species from southern California, using a combination of DNA barcoding and detailed morphological investigation employing highresolution X-ray microtomography (micro-CT). Chaetopterus dewysee sp. nov. is not only one of the most dominant annelids in the benthic communities of the shallow end of the La Jolla submarine canyon, but also a well-established model for studying bioluminescence and has a published transcriptome. The description and naming of this southern Californian Chaetopterus is a step towards the muchneeded revision of the group's taxonomy and towards resolving the confusion over the 'cosmopolitan' Chaetopterus variopedatus species complex. Micro-CT data showing details of both internal and external anatomy has been made freely available as the first annelid cybertype.
\end{abstract}

Keywords. Micro-CT, cybertype, COI, parchment worm, polychaete.

Tilic E. \& Rouse G.W. 2020. Hidden in plain sight, Chaetopterus dewysee sp. nov. (Chaetopteridae, Annelida)-Anew species from Southern California. European Journal of Taxonomy 643: 1-16. https://doi.org/10.5852/ejt.2020.643

\section{Introduction}

Chaetopteridae Audouin \& Milne Edwards, 1833 is a clade of mainly benthic, tubicolous annelids with an unusual body plan (Moore et al. 2017). The head is formed by a small prostomium and large peristomium, with two grooved palps. Following the head, chaetopterid bodies can be divided into three morphologically distinct regions: the anterior A region, middle $\mathrm{B}$ region and posterior $\mathrm{C}$ region (Fig. 1A). Each morphologically distinct body region undertakes a different function. In Chaetopterus Cuvier, 1830, region A, with its highly glandular ventral shield (plastron), is mainly involved in tube construction and mucus production, segments of region $\mathrm{B}$ are used for the elaborate mucous-feeding system (Fig. 1A). The notopodia of segments B3-5 form paddle like 'pistons' (Fig. 2A) that create suction and pump water through the worm's tube (Brown 1975, 1977). The cup-shaped cupule on segment B2 (Fig. 2A) forms and collects particles in a mucous net, which are then transported to the mouth opening along the ciliated groove (Fig. 2C). While grouped with spioniform annelids for the last 
few decades (Rouse \& Fauchald 1997; Rouse \& Pleijel 2001), recent molecular phylogenies of annelids recover Chaetopteridae isolated from most spioniform taxa (Andrade et al. 2015; Weigert \& Bleidorn 2016) forming a clade, Chaetopteriformia Fauchald, 1977, along with Apistobranchidae Mesnil \& Caullery, 1898and Psammodrilidae Swedmark, 1952 (Helm et al. 2018).

Chaetopterid taxonomy is not reliably resolved and a comprehensive revision is needed (Osborn et al. 2007; Moore et al. 2017). Especially within Chaetopterus, there is repeated confusion, mainly due to the synonymization of many species into a widely distributed and highly variable species $C$. variopedatus (Renier, 1804) by Fauvel (1927) and Hartman (1959), which has a type locality in the Mediterranean. In many other regions around the world, the name $C$. variopedatus was applied and no new species were named. Such is the case for US west coast, where Treadwell (1914) saw no reason not to use the European name for specimens he studied from southern California. This has been followed ever since for Chaetopterus from this region, with numerous records (see Hartman 1969) and studies (e.g., Brown 1975, 1977; Sumida 1983) referring to C. variopedatus, or more recently to Chaetopterus sp. (e.g., Deheyn et al. 2013; Weigand et al. 2017).

This taxonomic 'lumping' into a large, cosmopolitan species with an implied broad dispersal capacity was justified by the long planktonic stage of chaetopterid larvae in the water column (Scheltema 1974). However, it has been suggested repeatedly that $C$. variopedatus is a species complex of both morphologically (Petersen 1984a, 1984b; Petersen \& Britayev 1997) and molecularly distinct species (Osborn et al. 2007; Martin et al. 2008). Herein, we describe a long-unnamed Chaetopterus species from southern California. Chaetopterus dewysee sp. nov. occurs in large densities and makes up a large portion of the benthic biomass in the shallow reaches of the La Jolla submarine canyon (Fig. 1D). It is one of the most abundant and visually conspicuous annelid species with a reported population density of on average 20.8 individuals per $\mathrm{m}^{2}$ in Fisherman's Cove, Santa Catalina (Chess \& Hobson 1997). In addition to being one of the most dominant annelids in benthic communities, Chaetopterus dewysee sp. nov. is established as a model in the Scripps Institution of Oceanography and has been the focus of many studies investigating the biochemistry of light production and the bioluminescent properties of Chaetopterus mucus (Deheyn et al. 2013; Shah et al. 2014, 2015; Branchini et al. 2014; Rawat \& Deheyn 2016; Weigand et al. 2017). Chaetopterus dewysee sp. nov. also has a sequenced transcriptome (Accession No: SRX755856) and was included (as Chaetopterus sp. nov.) in large scale phylogenomic studies of Annelida (Andrade et al. 2015; Lemer et al. 2015). Together with our description of $C$. dewysee sp. nov. we provide the first three-dimensional annelid 'cybertype'. This micro-computed tomography dataset is freely available for future taxonomic and morphological investigations.

\section{Material and methods}

\section{Morphology}

Live specimens were studied and photographed with a Leica MZ9.5 stereo microscope mounted with a Canon EOS Rebel T5i digital camera. Chaetigers were dissected and placed on separate microscope slides, $50 \%$ bleach was used to dissolve the tissue. The tissue was slightly teased away from the chaetae. These were examined and photographed with a Leica DMR HC compound microscope. All animals were relaxed using $\mathrm{MgCl}_{2}$, fixed with $10 \%$ formaldehyde in seawater for a few days, rinsed in fresh water and transferred to $70 \%$ alcohol. Posterior parapodia were subsampled for DNA and fixed directly in $95 \%$ ethanol.

\section{Micro-CT}

The specimen fixed for micro-CT was preserved in 50\% ethanol. In order to stain soft tissue and increase contrast, the specimen was transferred to a $0.3 \%$ phosphotungstic acid (PTA) solution in $70 \%$ ethanol (Metscher 2009). The specimen remained in this solution for 3 months and was scanned using a Skyscan 
TILIC E. \& ROUSE G.W., Chaetopterus dewysee sp. nov.

1272 (Bruker microCT, Kontich, Belgium) with the following scan parameters: $60 \mathrm{kV}$ source voltage, $166 \mu \mathrm{A}$ source current, $741 \mathrm{~ms}$ exposure and a camera resolution of $1632 \times 1092 \mathrm{px}$. The voxel resolution was $8 \mu \mathrm{m}$. An aligned image stack was generated with the software Nrecon (Bruker) and the surface renderings were generated with the software Drishti 2.6.5. (National University, Canberra, Australia). Micro-CT data together with a 3D surface rendering are deposited online in the morphological data repository MorphDBase (Grobe \& Vogt 2009).

\section{DNA sequences}

DNA was extracted from posterior parapodia of animals using the Zymo Research Quick-DNATM Miniprep kit. DNA from the larva of Chaetopterus dewysee sp. nov. was extracted using the QuickDNA $^{\mathrm{TM}}$ Microprep kit. Up to $686 \mathrm{bp}$ of mitochondrial cytochrome c oxidase subunit I (COI) were amplified using the polyLCO/polyHCO primer set (Carr et al. 2011). Amplification was carried out using $8.5 \mu \mathrm{l}$ of ddH2O, $12.5 \mu \mathrm{l}$ of ApexTM 2.0x Taq RED DNA Polymerase Master Mix (Genesee Scientific), $1 \mu \mathrm{l}$ each of the forward and reverse primers $(10 \mu \mathrm{M})$, and $2 \mu 1$ of eluted DNA. The reactions were carried out in an Eppendorf thermal cycler. The COI reaction protocol was as follows: $94^{\circ} \mathrm{C} / 60 \mathrm{~s}$ $-\left(94^{\circ} \mathrm{C} / 40 \mathrm{~s}-45^{\circ} \mathrm{C} / 40 \mathrm{~s}-72^{\circ} \mathrm{C} / 60 \mathrm{~s}\right) * 5$ cycles $-\left(94^{\circ} \mathrm{C} / 40 \mathrm{~s}-51^{\circ} \mathrm{C} / 40 \mathrm{~s}-72^{\circ} \mathrm{C} / 60 \mathrm{~s}\right) * 35$ cycles $-72^{\circ} \mathrm{C} / 300 \mathrm{~s}$. Successfully amplified products were purified using $2 \mu 1$ of ExoSAP-IT PCR product cleaning reagent. The cleaned products were then sequenced by Eurofins Genomics (Louisville, KY) and assembled with Geneious ver. 11.0.2 (https://www.geneious.com). The COI sequence was also pulled from the assembly of the published Chaetopterus transcriptome (SRX755856) using the direct sequencing results as a blast query. Other available Chaetopterus COI sequences were acquired from GenBank, mostly from the Moore et al. (2017) study, but also including one $C$. dewysee sp. nov. sequence as, "Chaetopterus sp. 1", from Osborn et al. (2007) collected from Santa Barbara, California. Sequences of the sister group, Mesochaetopterus Potts, 1914, were used to root the phylogenetic analysis, following Moore et al. (2017).

All COI sequences included in the phylogenetic analysis (Table 1) were aligned using MAFFT (G-INS-i) (Katoh \& Standley 2013). The maximum likelihood analysis was executed with RaXML ver. 8.2.10 (Stamatakis 2014), with 1000 'thorough' bootstrap pseudoreplicates to assess clade support. A haplotype network of the nine Chaetopterus dewysee sp. nov. COI sequences was created with PopART ver. 1.7 (Leigh \& Bryant 2015) using the TCS algorithm.

\section{Repositories}

FLMNH $=$ Florida Museum of Natural History, Gainesville, USA

LACM = Natural History Museum of Los Angeles County, Los Angeles, USA

MNCN = Museo Nacional de Ciencias Naturales, Madrid, Spain

$\mathrm{SAM}=$ South Australian Museum, Adelaide, Australia

SIO-BIC $=$ Scripps Institution of Oceanography Benthic Invertebrate Collection, La Jolla, USA






\section{Results}

Family Chaetopteridae Audouin \& Milne Edwards, 1833

Genus Chaetopterus Cuvier, 1830

Chaetopterus dewysee sp. nov. urn:1sid:zoobank.org:act:B4B305E7-9A28-4632-9E58-A5A9A8E0A6D3

Figs 1-4

Chaetopterus variopedatus - Treadwell 1914: 204. - Hartman 1959: 396; 1969: 209. — Brown 1972: 278.; 1975: 136, figs 1, 4-8.; 1977: 121. — Sumida \& Case 1983: 249.

Chaetopterus sp. 1 - Osborn et al. 2007: 43. — Moore et al. 2017: 600.

Chaetopterus sp. - Deheyn et al. 2013: 702, fig. 1. - Branchini et al. 2014: 247, fig. 2. - Shah et al. 2014: 1, figs 1, 8.; 2015: 408, figs 1-6. - Lemer et al. 2015: 175. — Rawat \& Deheyn 2016: 1, fig. 1.

Chaetopterus sp. nov. - Andrade et al. 2015: 2863.

Chaetopterus - Weigand et al. 2017: 1, fig. 1.; Weigand et al. 2018: 1.

\section{Diagnosis}

Chaetopterus dewysee sp. nov. is characterized by having a long u-shaped tube partly buried in sediment, 10 region A chaetigers, 11-12 club-shaped a4 cutting chaetae with dark brown, coppery metallic coloration, a patch of notopodial uncini at the upper ventral margin of the modified b3-b5 notopodia.

\section{Etymology}

Named for Mary 'Dewy' White, for her support of the Rouse lab and her passion for conservation and marine biological research. Based on her love of the sea we have incorporated the German word 'See' into the name.

\section{Material examined}

\section{Holotype}

UNITED STATES OF AMERICA • adult specimen with tube; California, San Diego, Scripps Submarine Canyon; 3252'11.35" N, 117²15'36.00" W; depth 20 m; 2019; Phil Zerofski leg.; GenBank: MN991231; SIO-BIC A11476.

\section{Paratypes}

UNITED STATES OF AMERICA - 1 adult specimen; same collection data as for holotype; GenBank: MN991233; SIO-BIC A10193 - 1 adult specimen; same collection data as for holotype; 18 Feb. 2010; Eddie Kisfaludy leg.; GenBank: MN991236; SIO-BIC A4193 • 1 adult specimen; California, San Diego, La Jolla Submarine Canyon; 24 Jul. 2008; Eddie Kisfaludy leg.; GenBank: MN991230; SIO-BIC A11649 • 1 adult specimen; same collection data as for holotype; 2017; Greg Rouse leg.; GenBank: MN991235; SIO-BIC A11652 1 adult specimen; California, San Diego, Scripps Institution of Oceanography pier; Nov. 2017; Avery Hatch and Ekin Tilic leg.; GenBank: MN991234; SIO-BIC A11653 1 adult specimen; same collection data as for preceding; 5 Jul. 2019; Ekin Tilic leg.; SIO-BIC A12034 (cybertype).

\section{Cybertype}

Complete micro-CT scan of a paratype SIO-BIC A12034, designated as cybertype.

Direct link to online specimen: www.morphdbase.de/?E_Tilic_20200122-S-5.1 

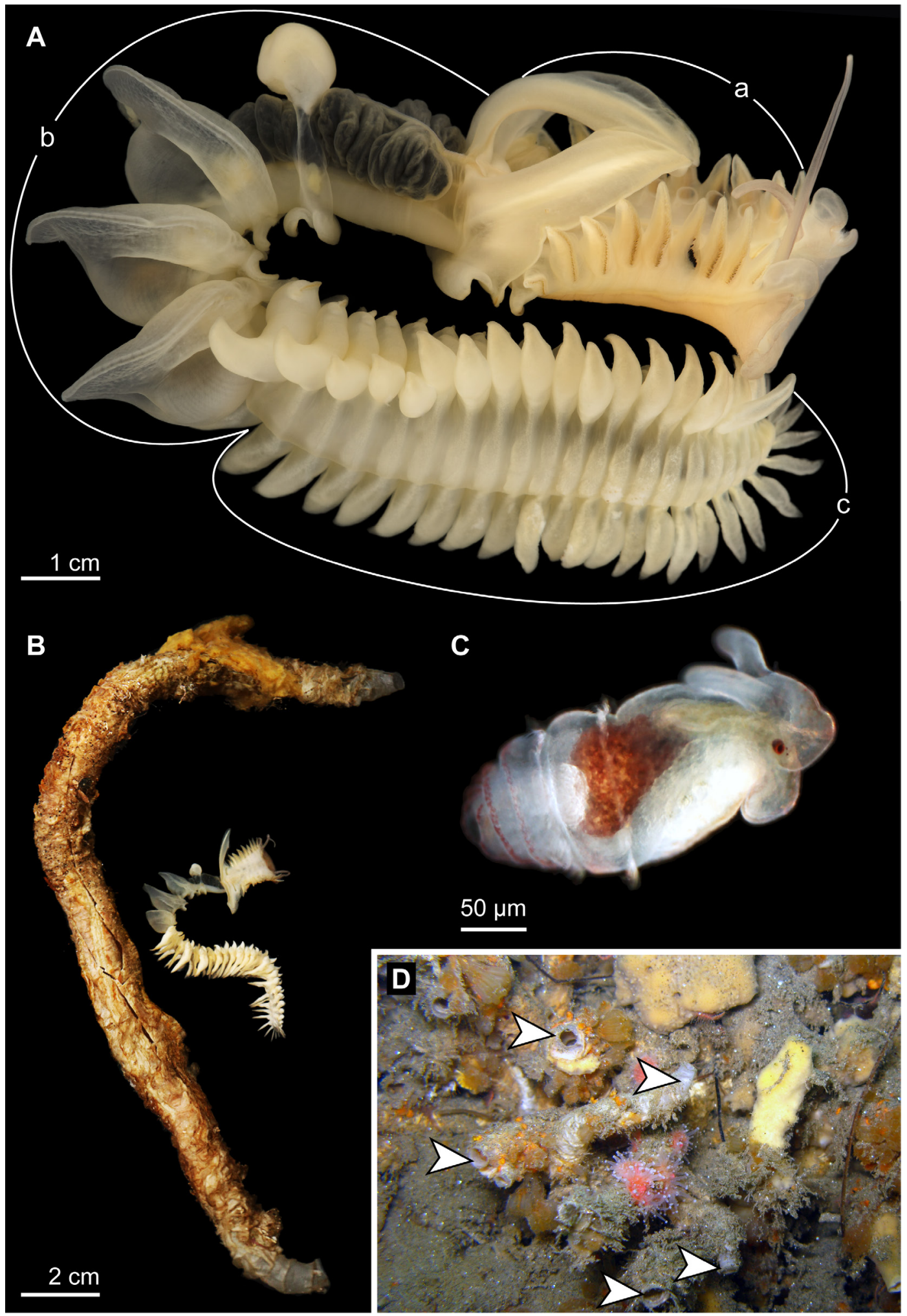

Fig. 1. Chaetopterus dewysee sp. nov. A. Live photograph of a paratype (SIO-BIC A11652), showing the three morphologically distinct regions of a chaetopterid annelid; $\mathrm{a}=$ region $\mathrm{A}, \mathrm{b}=$ region $\mathrm{B}, \mathrm{c}=$ region C. B. Holotype together with its tube (SIO-BIC A11476). C. Larva of Chaetopterus dewysee sp. nov. collected from a plankton sample off La Jolla and sequenced (GenBank: MN991232). D. Habitat of the new species, tubes are marked with arrow-heads. 
Direct links to the micro-CT stack:

PART 1/3: www.morphdbase.de/?E_Tilic_20200122-M-42.1

PART 2/3: www.morphdbase.de/?E_Tilic_20200122-M-41.1

PART 3/3: www.morphdbase.de/?E_Tilic_20200122-M-40.1

Direct link to 3D surface rendering: www.morphdbase.de/?E_Tilic_20200122-M-43.1

\section{Description}

Total body length of holotype $55 \mathrm{~mm}$ (paratypes: A12034 $=35 \mathrm{~mm}, \mathrm{~A} 11652=180 \mathrm{~mm}, \mathrm{~A} 11653=$ $107 \mathrm{~mm}$ ). Region A with 10 chaetigers. Prostomium small, with anterior border rounded, entire. Peristomium extended, completely covering prostomium; wide horseshoe-shaped in anterior view (Figs 2A, 4C). Two grooved palps extending beyond peristomium, length $7.5 \mathrm{~mm}$ (Fig. 2A). Paired eyes present, located at the base of palps (Fig. 2B). Middorsal ciliated groove (cg) extending from region B through region $\mathrm{A}$, ending near the mouth opening with a conical ridge (Fig. 2C-B). Ventral surface of region A with a smooth plastron (ventral shield) (Figs 1A, 4B): length $9 \mathrm{~mm}$, width $3.9 \mathrm{~mm}$. First 9 chaetigers uniramous. Tenth chaetiger (a10) biramous, with long notopodium and a neuropodial lobe (Fig. 3A). Each notopodium with 2-3 rows of light yellow lanceolate chaetae. Neuropodial uncini of chaetiger a10 with 5-6 teeth, short rostral and long adrostral process (Fig. 3B). Chaetiger a4 with 11-12 modified cutting chaetae (Fig. 2C-E). Modified chaetae dark brown, with coppery metallic shimmer, club-shaped, tip asymmetrical, truncated with sharp apical point (Fig. 2E). Larger portion of cutting chaetae embedded inside the chaetiger (Figs 2D, 4E). Region B with five chaetigers, with biramous parapodia. Digestive gland blackish green in living specimens; coloration lost in ethanol-preserved specimens. Chaetiger b1 with distally tapering, aliform notopodia extending to the middle of region $\mathrm{A}$ (Figs 2C, 3D): length $9.2 \mathrm{~mm}$ (paratypes: A12034 =11 mm, A11652 = $28 \mathrm{~mm}$, A11653 = $26.4 \mathrm{~mm}$ ). Chaetiger b2 modified with large cupule (Figs 2A, 4A-B). Notopodia of b3-b5 fused middorsally, forming enlarged fans (Figs 2A, 4A). Small pocket with patch of uncini at the upper ventral margin of the enlarged fan (Fig. 3C, E). Notopodial uncini of chaetigers b3-b5 with 9-10 teeth, shorter adrostral process and a long rostral process (Fig. 3F). Neuropodium of chaetiger b1 with upper and lower row of uncini (Fig. 3D), b3-5 only with one lower row of uncini (Fig. 3C). Region C with 16 chaetigers (paratypes: A12034 = 10, A11652 = 19, A11653 = 17). Parapodia biramous. Notopodia long, with distally tapering tip and internal acicular chaetae (Fig. 3G). Neuropodia bilobed; lateral lobe with no cirrus on lateral side; ventral neuropodial lobe without cirrus (Fig. 3G). Lateral lobe uncini of region $\mathrm{C}$ arranged in 2-3 rows (Fig. $3 \mathrm{H}$ ), chaetiger $\mathrm{c} 1$ uncini similar to those of chaetiger a10, with 5-6 teeth (Fig. 3I).

\section{Tube}

Parchment like, U-shaped tube, sometimes with sand debris and shell fragments on the outer surface (Fig. 1B). Both tube openings almost half in diameter $(8 \mathrm{~mm})$ compared to the middle section of the tube (16 mm). Total tube length $293 \mathrm{~mm}$.

\section{Habitat}

Commonly found partially buried along canyon walls in large assemblages of solitary, intermingled tubes and sediment with other fauna, such as sponges and tunicates.

\section{Distribution}

Southern California. COI sequences confirm the identity of Chaetopterus sp. 1 from Santa Barbara (Osborn et al. 2007; Moore et al. 2017) as C. dewysee sp. nov. (Fig. 5) 

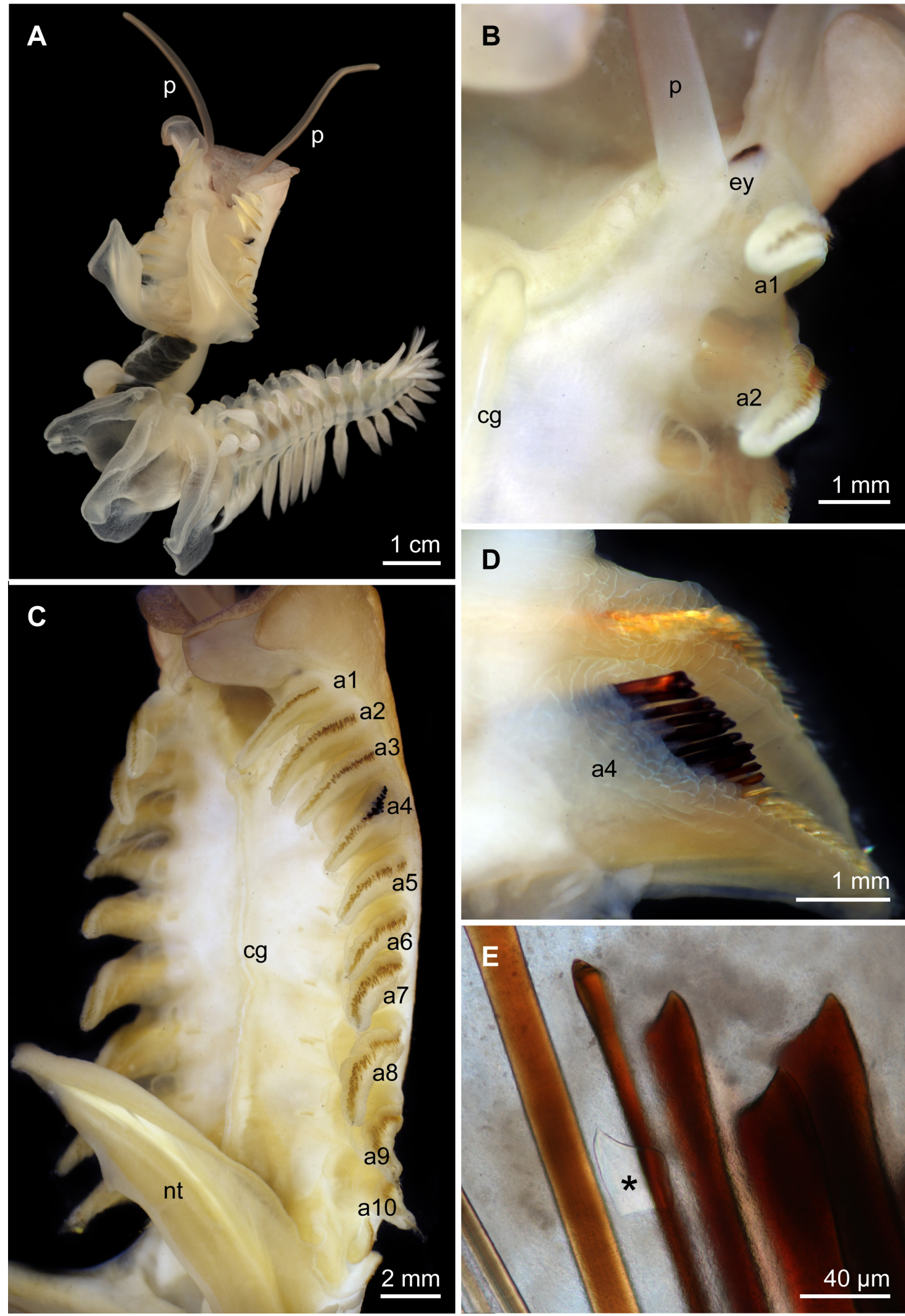

Fig. 2. Chaetopterus dewysee sp. nov. A. Habitus of a paratype (SIO-BIC A11653). B-C. Anterior region A, chaetigers are numbered a1-10. D-E. Details of chaetiger a4 cutting chaetae; * marks a developing cutting chaeta. $\mathrm{p}=$ palps, ey $=$ eyes, $\mathrm{cg}=$ ciliated groove, $\mathrm{nt}=$ notopodium . 



Fig. 3. Chaetopterus dewysee sp. nov. A. Biramous chaetiger a10 parapodium with a long notopodium and a neuropodial lobe. B. Neuropodial uncinus of chaetiger a10. C. Chaetiger b3 neuropodium with one row of uncini, arrow-head marks the patch of uncini (E) at the upper ventral margin of enlarged fan. D. Aliform notopodium of chaetiger b1. F. Notopodial uncinus of chaetiger b3. G. Biramous region C parapodia. H. Uncini of region C lateral lobe arranged in 2-3 rows. I. Chaetiger c1 uncinus of lateral lobe. 


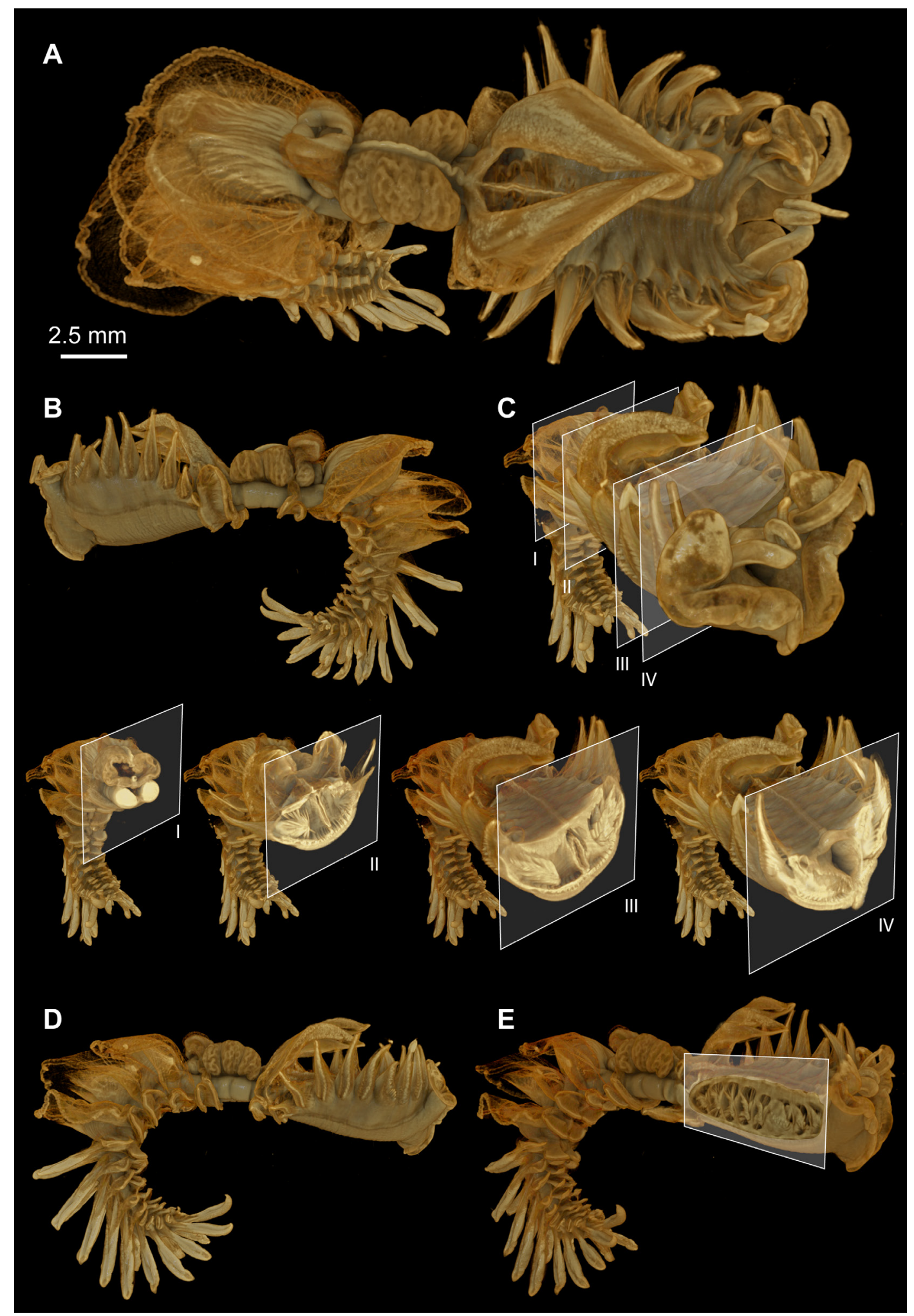

Fig. 4. Chaetopterus dewysee sp. nov. micro-CT surface renderings of the cybertype (SIO-BIC A12034). A. Dorsal view of the whole specimen. B. Lateral view of the whole specimen. C. Frontal view with virtual dissection planes (I-III) showing cross-sections along the body. D-E. Lateral view with a virtual dissection window showing the parapodial musculature of region A. Direct link to cybertype: www.morphdbase.de/?E_Tilic_20200122-S-5.1 


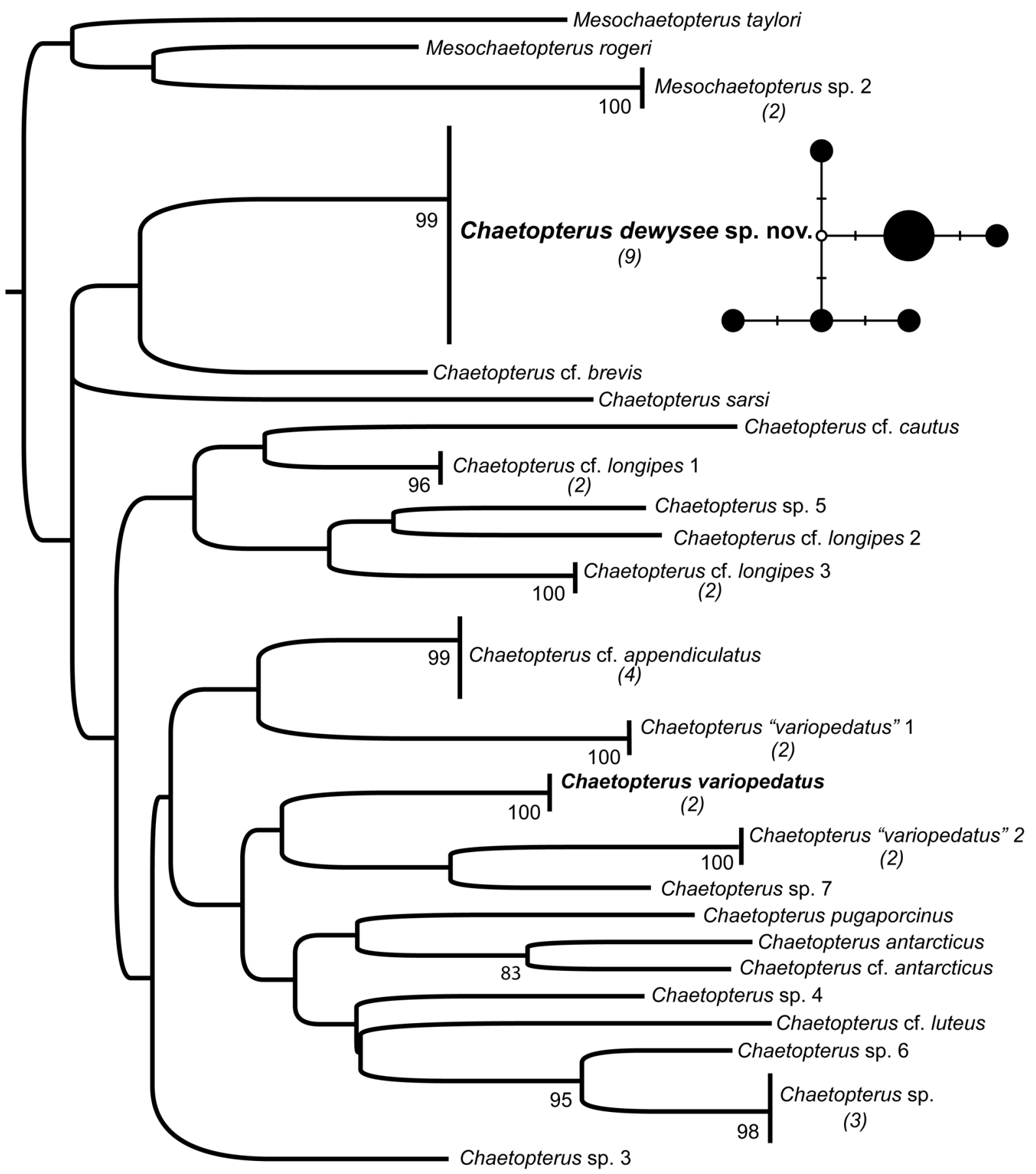

0.3

Fig. 5. Maximum likelihood tree of Chaetopterus Cuvier, 1830 spp. COI sequences with the Mesochaetopterus Potts, 1914 clade as outgroup, based on Moore et al. (2017). Only bootstrap supports $>80$ are shown. The new species Chaetopterus dewysee sp. nov. and C. variopedatus (Renier, 1804) from the type locality are in bold. Number of sequences included for each terminal is in brackets. Details on sequences that were analyzed can be found in Table 1. Haplotype network for the nine Chaetopterus dewysee sp. nov. sequences is shown next to the tree. 
TILIC E. \& ROUSE G.W., Chaetopterus dewysee sp. nov.

Table 1. List of sequenced Chaetopterus dewysee sp. nov. specimens and analyzed COI sequences with GenBank repository, voucher and locality information. Species names are listed as they are shown in Fig. 5. New sequences are in bold. Voucher holding institution abbreviations are: SIO-BIC $=$ Scripps Institution of Oceanography Benthic Invertebrate Collection; FLMNH = Florida Museum of Natural History; SAM = South Australian Museum; LACM = Natural History Museum of Los Angeles County; $\mathrm{MNCN}=$ Museo Nacional de Ciencias Naturales.

\begin{tabular}{|c|c|c|c|}
\hline Terminal & GenBank No. & Voucher ID & Locality \\
\hline Mesochaetopterus taylori & DQ209251 & SAM E3570 & Friday Harbor, WA \\
\hline Mesochaetopterus rogeri & AM503098 & MNCN 6.01/10145 & Blanes, Spain \\
\hline Mesochaetopterus sp. 2 & KX896518 & FLMNH UF 1971 & Moorea, FP \\
\hline Mesochaetopterus sp. 2 & KC706790 & - & Moorea, FP \\
\hline Chaetopterus dewysee sp. nov. & DQ209252 & SAM E3511 & Santa Barbara, CA \\
\hline Chaetopterus dewysee sp. nov. & MN991233 & SIO-BIC A10193 & San Diego, CA \\
\hline Chaetopterus dewysee sp. nov. & MN991236 & SIO-BIC A4193 & San Diego, CA \\
\hline Chaetopterus dewysee sp. nov. & MN991231 & SIO-BIC A11476 holotype & San Diego, CA \\
\hline Chaetopterus dewysee sp. nov. & MN991230 & SIO-BIC A11649 & San Diego, CA \\
\hline Chaetopterus dewysee sp. nov. & MN991235 & SIO-BIC A11652 & San Diego, CA \\
\hline Chaetopterus dewysee sp. nov. & MN991234 & SIO-BIC A11653 & San Diego, CA \\
\hline Chaetopterus dewysee sp. nov. & MN991232 & — * larva not vouchered & San Diego, CA \\
\hline Chetopterus cf. brevis & DQ209255 & - & Banyuls, France \\
\hline Chaetopterus sarsi & DQ209254 & SAM E3557 & Trondheimsfjord, NO \\
\hline Chaetopterus cf. cautus & KX896511 & FLMNH UF 4676 & Kavieng, PNG \\
\hline Chatopterus $\mathrm{cf}$. longipes 1 & KX896491 & SIO-BIC A2831 & Moorea, FP \\
\hline Chatopterus $\mathrm{cf}$. longipes 1 & KX896515 & FLMNH UF 1697 & Guam \\
\hline Chaetopterus sp. 5 & KX896510 & FLMNH UF 4675 & Kavieng, PNG \\
\hline Chaetopterus cf. longipes 2 & KX896502 & SIO-BIC A3625 & Lizard Island, AUS \\
\hline Chaetopterus cf. longipes 3 & KX896513 & FLMNH UF 551 & Moorea, FP \\
\hline Chaetopterus cf. longipes 3 & KX896519 & FLMNH UF 2652 & St. Martin \\
\hline Chaetopterus cf. appendiculatus & KY124465 & - & Vietnam \\
\hline Chaetopterus cf. appendiculatus & KY124466 & - & Vietnam \\
\hline Chaetopterus cf. appendiculatus & KY124467 & - & Vietnam \\
\hline Chaetopterus cf. appendiculatus & KY124468 & - & Vietnam \\
\hline Chaetopterus "variopedatus" 1 & MF120993 & - & Alaska, USA \\
\hline Chaetopterus "variopedatus" 1 & MF121353 & - & Alaska, USA \\
\hline Chaetopterus "variopedatus" 2 & AM503096 & - & Norwich, Norfolk, UK \\
\hline Chaetopterus "variopedatus" 2 & DQ087501 & - & - \\
\hline Chaetopterus variopedatus & AM503094 & - & Naples, Italy \\
\hline Chaetopterus variopedatus & KX896523 & FLMNH UF 4257 & Adriatic Sea \\
\hline Chaetopterus sp. 7 & KX896506 & - & Baja California \\
\hline Chaetopterus pugaporcinus & DQ209257 & LACM POLY 2173-2175 & Monterey Bay, CA \\
\hline Chaetopterus antarcticus & KX896494 & SIO-BIC A2929 & Burdwood Bank \\
\hline Chaetopterus cf. antarcticus & KX896493 & SIO-BIC A2978 & Scotia Arc \\
\hline Chaetopterus sp. 4 & KX896509 & FLMNH UF 4674 & Kavieng, PNG \\
\hline Chaetopterus cf. luteus & DQ209253 & SAM E3510 & South Australia \\
\hline Chaetopterus sp. 6 & KX896505 & FLMNH UF 4678 & Red Sea \\
\hline Chaetopterus sp. & KY124469 & - & Vietnam \\
\hline Chaetopterus sp. & KY124471 & - & Vietnam \\
\hline Chaetopterus sp. & KY124470 & - & Vietnam \\
\hline Chaetopterus sp. 3 & KX896508 & FLMNH UF 4673 & Kavieng, PNG \\
\hline
\end{tabular}




\section{Molecular information}

All type specimens of Chaetopterus dewysee sp. nov., except for the cybertype, were subsampled and sequenced for COI (Table 1). The specimen chosen for the micro-CT scan was kept intact as a cybertype. All COI sequences for specimens identified as Chaetopterus dewysee sp. nov. were $>98.8 \%$ similar. These included the COI sequence pulled from the available Chaetopterus transcriptome, the sequence from Santa Barbara, published by Osborn et al. (2007) and the COI sequence from the larva (Fig. 1C). The haplotype network for the nine $C$. dewysee sp. nov. sequences (Fig. 5) shows minor variation amongst the specimens. The most frequent haplotype is shared by four individuals (the sequenced larva, the holotype A11476, A10193 and A11653). In addition to this, there are 5 low-frequency haplotypes, each represented by a single specimen. The haplotypes are separated by one to three mutational steps. On the maximum likelihood tree sequences that were more than $97 \%$ similar were given the same terminal name and the branches were collapsed (Fig. 5). Average identity between the COI sequences of different Chaetopterus spp. was $78.7 \%$ ( $\min .72 .1 \%$, max 85.2\%).

\section{Remarks}

Chaetopterus dewysee sp. nov. most resembles the two European species, C. brevis Lespés, 1872 and $C$. variopedatus. The main difference between the 3 species is in the morphology of a 4 cutting chaetae. Chaetopterus variopedatus has a4 cutting chaetae with teeth, whereas the cutting chaetae of C. brevis are symmetrical and distally inflated. In C. dewysee sp. nov. the cutting chaetae have a smooth, asymmetrical tip with a sharp apical point. Furthermore, region $C$ notopodia of $C$. dewysee sp. nov. have no lateral cirrus, which is present in both $C$. brevis and C. variopedatus. Chaetopterus brevis also differs from the other two species in having a gregarious habit, that can be occupied by multiple individuals. Relationships were not supported across most of the phylogeny generated here using COI (Fig. 5). Chaetopterus dewysee sp. nov. is sister group to Chaetopterus cf. brevis from France, but with low support. In Moore et al. (2017), which also used nuclear 18S and 28S data, this relationship was also recovered, but with very strong support.

Other Chaetopterus species described from the eastern Pacific (Galapagos Islands) are C. galapagensis Nishi, Hickman \& Bailey-Brock, 2009, C. adunctus Nishi, Hickman \& Bailey-Brock, 2009 and C. charlesdarwinii Nishi, Hickman \& Bailey-Brock, 2009. Chaetopterus adunctus has a J-shaped and $C$. darwinii a U-shaped tube, both attached to rocks (Nishi et al. 2009), whereas the new species $C$. dewysee sp. nov. has tubes partly buried in sediment. The obvious main difference among the species is the number of region A chaetigers: C. charlesdarwinii only has 9, C. galapagensis 13-15 and C. dewysee sp. nov. has 10 . The three species also differ in the number of teeth on the chaetiger $\mathrm{c} 1$ lateral lobe uncini; $C$. dewysee sp. nov. only has 5-6 teeth whereas $C$. adunctus has 10-11, C. charlesdarwinii has 9-11 and C. galapagensis 7-8 teeth (Nishi et al. 2009).

\section{Discussion}

The concept of 'cybertypes' was introduced by Faulwetter et al. (2013) and in the same paper the potential of micro computed tomography as a taxonomic resource was illustrated using examples from different annelid species. Micro-CT scanning has been used for species descriptions in arthropods and there are several cybertypes available for myriapods (Stoev et al. 2013; Akkari et al. 2015) and ants (Hita Garcia et al. 2017). According to the definition of Faulwetter et al. (2013), a cybertype needs to: (a) provide morphological and anatomical information of at least the same accuracy as a physical type, that is not linked to a specific research question; (b) a cybertype should be associated with an original type; (c) a cybertype has to be made freely accessible.

Virtual dissections together with contrast enhancing stains significantly improve the resolution of anatomical details of otherwise inconspicuous soft-tissue (Fig. 4C, E) and micro-CT is becoming more 
common as a tool to study the internal anatomy of annelids (Paterson et al. 2014). The advantages of a non-invasive technique like micro-CT are clear as this technique allows a detailed imaging of historical and valuable museum specimens. Furthermore, these methods are significantly less labor-intensive than traditional histology and allow a more automated workflow that can generate large amounts of morphological data in a shorter period of time. Another great advantage is how the volume data generated shows anatomical structures in their original arrangement and thus enables automated image processing for anatomical 3D reconstructions. Micro-CT might not be able to provide the high cell-level resolution of serial histology, but certain internal details of the myoanatomy (Fig. 4C, E), digestive system (Parapar et al. 2017), nervous system (Beckers et al. 2019) and hard structures, like jaws, in annelids (Watson \& Faulwetter 2017) can be visualized in great detail.

The micro-CT dataset and 3D renderings of Chaetopterus dewysee sp. nov. (SIO-BIC A12034) we provide here constitute the first annelid cybertype which is freely available for future research on this species.

\section{Acknowledgments}

ET was supported by a personal research fellowship of the German Research Foundation, DFG (TI 973/1-1). We are grateful to Phil Zerofski, marine collector at SIO, who collected and kept the animals in the Marine Biology Experimental Aquarium Facility at SIO. We would like to thank Dr Alexander Ziegler for providing his support with the micro-CT scan. The micro-CT-scanner used for this investigation was funded by the DFG (INST 217/849-1 FUGG). We would also like to thank Charlotte Seid (SIO-BIC) for collections management, Sonya Timko for finding the Chaetopterus dewysee sp. nov. larva and Avery Sea Hatch for DNA extraction and sequencing.

\section{References}

Akkari N., Enghoff H. \& Metscher B.D. 2015. A new dimension in documenting new species: highdetail imaging for myriapod taxonomy and first 3D cybertype of a new millipede species (Diplopoda, Julida, Julidae). PloS ONE 10 (8): e0135243. https://doi.org/10.1371/journal.pone.0135243

Andrade S.C.S., Novo M., Kawauchi G.Y., Worsaae K., Pleijel F., Giribet G. \& Rouse G.W. 2015. Articulating 'archiannelids': Phylogenomics and annelid relationships, with emphasis on meiofaunal taxa. Molecular Biology and Evolution 32 (11): 2860-2875. https://oi.org/10.1093/molbev/msv157

Beckers P., Helm C., Purschke G., Worsaae K., Hutchings P. \& Bartolomaeus T. 2019. The central nervous system of Oweniidae (Annelida) and its implications for the structure of the ancestral annelid brain. Frontiers in Zoology 16, 6. https://doi.org/10.1186/s12983-019-0305-1

Branchini B.R., Behney C.E., Southworth T.L., Rawat R. \& Deheyn D.D. 2014. Chemical analysis of the luminous slime secreted by the marine worm Chaetopterus (Annelida, Polychaeta). Photochemistry and Photobiology 90 (1): 247-251. https://doi.org/10.1111/php.12169

Brown S.C., Bdzil J.B. \& Frisch H.L. 1972. Responses of Chaetopterus variopedatus to osmotic stress, with a discussion of the mechanism of isoosmotic volume-regulation. The Biological Bulletin 143 (2): 278-295. https://doi.org/10.2307/1540053

Brown S.C. 1975. Biomechanics of water-pumping by Chaetopterus variopedatus Renier. skeletomusculature and kinematics. The Biological Bulletin 149: 136-150. https://doi.org/10.2307/1540485

Brown S.C. 1977. Biomechanics of water-pumping by Chaetopterus variopedatus Renier: Kinetics and hydrodynamics. The Biological Bulletin 153: 121-132. https://doi.org/10.2307/1540696 
Carr C.M., Hardy S.M., Brown T.M., Macdonald T.A. \& Hebert P.D. 2011. A tri-oceanic perspective: DNA barcoding reveals geographic structure and cryptic diversity in Canadian polychaetes. PLoS ONE 6 (7): e22232. https://doi.org/10.1371/journal.pone.0022232

Chess J. \& Hobson E.S. 1997. Benthic invertebrates of four Southern California marine habitats prior to onset of ocean warming in 1976, with lists of fish predators. NOAA Technical Memorandum NMFSSWFSC 243: 1-110.

Deheyn D.D., Enzor L.A., Dubowitz A., Urbach J.S. \& Blair D. 2013. Optical and physicochemical characterization of the luminous mucous secreted by the marine worm Chaetopterus sp. Physiological and Biochemical Zoology 86 (6): 702-705. https://doi.org/10.1086/673869

Faulwetter S., Vasileiadou A., Kouratoras M., Dailianis T. \& Arvanitidis C. 2013. Micro-computed tomography: Introducing new dimensions to taxonomy. ZooKeys 263: 1-45.

https://doi.org/10.3897/zookeys.263.4261

Fauvel P. 1927. Polychètes sédentaires. Addenda aux errantes, archiannélides, myzostomaires. Faune de France 16: 1-494.

Grobe P. \& Vogt L. 2009. Morph.D.Base 2.0: A public data base for morphological data, metadata, and phylogenetic matrices. Available from http://www.morphdbase.de [accessed 09 March 2020].

Hartman O. 1959. Catalogue of the polychaetous annelids of the world. Parts 1 and 2. Allan Hancock Foundation Occasional Paper 23: 1-628.

Hartman O. 1969. Atlas of the Sedenteriate Polychaetous Annelids from California. Allan Hancock Foundation University of Southern California, Los Angeles.

Helm C., Beckers P., Bartolomaeus T., Drukewitz S.H., Kourtesis I., Weigert A., Purschke G., Worsaae K., Struck T.H. \& Bleidorn C. 2018. Convergent evolution of the ladder-like ventral nerve cord in Annelida. Frontiers in Zoology 15, 36. https://doi.org/10.1186/s12983-018-0280-y

Hita Garcia F., Fischer G., Liu C., Audisio T.L., Alpert G.D., Fisher B.L. \& Economo E.P. 2017. X-Ray microtomography for ant taxonomy: An exploration and case study with two new Terataner (Hymenoptera, Formicidae, Myrmicinae) species from Madagascar. PloS ONE 12 (3): e 0172641. https://doi.org/10.1371/journal.pone.0172641

Katoh K. \& Standley D.M. 2013. MAFFT multiple sequence alignment software version 7: improvements in performance and usability. Molecular Biology and Evolution 30 (4): 772-780.

https://doi.org/10.1093/molbev/mst010

Leigh J.W. \& Bryant D. 2015. POPART: full-feature software for haplotype network construction. Methods in Ecology and Evolution 6 (9): 1110-1116. https://doi.org/10.1111/2041-210X.12410

Lemer S., Kawauchi G.Y., Andrade S.C.S., González V.L., Boyle M.J. \& Giribet G. 2015. Re-evaluating the phylogeny of Sipuncula through transcriptomics. Molecular Phylogenetics and Evolution 83: 174183. https://doi.org/10.1016/j.ympev.2014.10.019

Martin D., Gil J., Carreras-Carbonell J. \& Bhaud M. 2008. Description of a new species of Mesochaetopterus (Annelida, Polychaeta, Chaetopteridae), with redescription of Mesochaetopterus xerecus and an approach to the phylogeny of the family. Zoological Journal of the Linnean Society 152 (2): 201-225. https://doi.org/10.1111/j.1096-3642.2007.00342.x

Metscher B.D. 2009. MicroCT for comparative morphology: simple staining methods allow highcontrast 3D imaging of diverse non-mineralized animal tissues. BMC Physiology 9, 11.

https://doi.org/10.1186/1472-6793-9-11 
TILIC E. \& ROUSE G.W., Chaetopterus dewysee sp. nov.

Moore J.M., Nishi E. \& Rouse G.W. 2017. Phylogenetic analyses of Chaetopteridae (Annelida). Zoologica Scripta 46: 596-610. https://doi.org/10.1111/zsc.12238

Nishi E., Hickman C.P. Jr., Bailey-Brock J.H. 2009. Chaetopterus and Mesochaetopterus (Polychaeta: Chaetopteridae) from the Galapagos Islands, with descriptions of four new species. Proceedings of the Academy of Natural Sciences of Philadelphia 158: 239-259. https://doi.org/10.1635/053.158.0113

Osborn K.J., Rouse G.W., Goffredi S.K. \& Robison B.H. 2007. Description and relationships of Chaetopterus pugaporcinus, an unusual pelagic polychaete (Annelida, Chaetopteridae). The Biological Bulletin 212 (1): 40-54. https://doi.org/10.2307/25066579

Parapar J., Candás M., Cunha-Veira X. \& Moreira J. 2017. Exploring annelid anatomy using microcomputed tomography: A taxonomic approach. Zoologischer Anzeiger 270: 19-42.

https://doi.org/10.1016/j.jcz.2017.09.001

Paterson G.L.J., Sykes D., Faulwetter S., Merk R., Ahmed F., Hawkins L.E., Dinley J., Ball A.D. \& Arvanitidis C. 2014. The pros and cons of using micro-computed tomography in gross and microanatomical assessments of polychaetous annelids. Memoirs of Museum Victoria 71: 237-246. http://doi.org/10.24199/j.mmv.2014.71.18

Petersen M.E. 1984a. Chaetopterus variopedatus (Renier) (Annelida: Polychaeta: Chaetopteridae) a species complex. What species are being used at MBL? The Biological bulletin 167: 513.

Petersen M.E. 1984b. Chaetopterus variopedatus (Annelida: Polychaeta): another victim of the 'characteristic species' diseases. American Zoologist 23: 62A.

Petersen M.E. \& Britayev T.A. 1997. A new genus and species of polynoid scaleworm commensal with Chaetopterus appendiculatus Grube from the Banda Sea (Annelida: Polychaeta), with a review of commensals of Chaetopteridae. Bulletin of Marine Science 60 (2): 261-276.

Rawat R. \& Deheyn D.D. 2016. Evidence that ferritin is associated with light production in the mucus of the marine worm. Chaetopterus. Scientific Reports 6: 36854. https://doi.org/10.1038/srep36854

Rouse G.W. \& Fauchald K. 1997. Cladistics and polychaetes. Zoologica Scripta 26 (2): 139-204. https://doi.org/10.1111/j.1463-6409.1997.tb00412.x

Rouse G.W. \& Pleijel F. 2001. Polychaetes. Oxford University Press, Oxford.

Scheltema R.S. 1974. Relationship of dispersal to geographical distribution and morphological variation in the polychaete family Chaetopteridae. Thalassia Jugoslavia 10: 297-312.

Shah D.U., Vollrath F., Porter D., Stires J. \& Deheyn D.D. 2014. Housing tubes from the marine worm Chaetopterus sp.: biomaterials with exceptionally broad thermomechanical properties. Journal of the Royal Society Interface 11 (98): 20140525. https://doi.org/10.1098/rsif.2014.0525

Shah D.U., Vollrath F., Stires J. \& Deheyn D.D. 2015. The biocomposite tube of a chaetopterid marine worm constructed with highly-controlled orientation of nanofilaments. Materials Science and Engineering C 48: 408-415. https://doi.org/10.1016/j.msec.2014.12.015

Stamatakis A. 2014. RAxML version 8: a tool for phylogenetic analysis and post-analysis of large phylogenies. Bioinformatics 30 (9): 1312-1313. https://doi.org/10.1093/bioinformatics/btu033

Stoev P., Komerički A., Akkari N., Liu S., Zhou X., Weigand A.M., Hostens J., Hunter C.I., Edmunds S.C., Porco D., Zapparoli M., Georgiev T., Mietchen D., Roberts D., Faulwetter S., Smith V. \& Penev L. 2013. Eupolybothrus cavernicolus Komerički \& Stoev sp. n. (Chilopoda: Lithobiomorpha: Lithobiidae): the first eukaryotic species description combining transcriptomic, DNA barcoding and micro-CT imaging data. Biodiversity data journal 1: e1013. https://doi.org/10.3897/BDJ.1.e1013 
Sumida B.H. \& Case J.F. 1983. Food recognition by Chaetopterus variopedatus (Renier): synergy of mechanical and chemical stimulation. Marine Behaviour and Physiology 9: 249-174.

https://doi.org/10.1080/10236248309378597

Treadwell A.L. 1914. Polychaetous annelids of the Pacific Coast in the collections of the Zoological Museum of the University of California. University of California Publications in Zoology 13: 175-234.

Watson C. \& Faulwetter S. 2017. Stylet jaws of Chrysopetalidae (Annelida). Journal of Natural History 51 (47-48): 2863-2924. https://doi.org/10.1080/00222933.2017.1395919

Weigand W.J., Messmore A., Tu J., Morales-Sanz A., Blair D.L., Deheyn D.D., Urbach J.S. \& Robertson-Anderson R.M. 2017. Active microrheology determines scale-dependent material properties of Chaetopterus mucus. PloS ONE 12 (5): e0176732. https://doi.org/10.1371/journal.pone.0203102

Weigand W.J., Messmore A., Tu J., Morales-Sanz A., Blair D.L., Deheyn D.D., Urbach J.S. \& RobertsonAnderson R.M. 2018. Correction: Active microrheology determines scale-dependent material properties of Chaetopterus mucus. PloS ONE 13 (8): e0203102. https://doi.org/10.1371/journal.pone.0203102

Weigert A. \& Bleidorn C. 2016. Current status of annelid phylogeny. Organisms Diversity and Evolution 16: 345-362. https://doi.org/10.1007/s13127-016-0265-7

Manuscript received: 26 January 2020

Manuscript accepted: 24 March 2020

Published on: 11 May 2020

Topic editor: Rudy C.A.M. Jocqué

Desk editor: Radka Rosenbaumová

Printed versions of all papers are also deposited in the libraries of the institutes that are members of the EJT consortium: Muséum national d'histoire naturelle, Paris, France; Meise Botanic Garden, Belgium; Royal Museum for Central Africa, Tervuren, Belgium; Royal Belgian Institute of Natural Sciences, Brussels, Belgium; Natural History Museum of Denmark, Copenhagen, Denmark; Naturalis Biodiversity Center, Leiden, the Netherlands; Museo Nacional de Ciencias Naturales-CSIC, Madrid, Spain; Real Jardín Botánico de Madrid CSIC, Spain; Zoological Research Museum Alexander Koenig, Bonn, Germany; National Museum, Prague, Czech Republic. 